\title{
FINANCIAL CONTROL OF FUNDS CO-FINANCED FROM THE EU BUDGET: POSSIBILITIES OF CONSIDERING NEW AND MORE FAVORABLE LEGAL PROVISIONS
}

\begin{abstract}
This paper presents secondary control of funds co-financed from the EU budget and the possibility of taking into account new and (for the recipients of funds) more favourable legal provisions. This applies to situations when the beneficiary implementing an expenditure breaches regulations which are later, e.g. at the time of auditing, generally not regarded as illegal behaviour. In this meaning, it is necessary to distinguish between the general principle of punishment and rules based on the principle of sound financial management and the recovery of unduly granted funds.
\end{abstract}

\section{Key words}

Financial control; budget EU; status of audit

\section{Introduction}

In my contribution I would like to focus on secondary control of funds co-financed from the EU budget and the possibility of taking into account new and (for the recipients of funds) more favourable legal provisions. This applies to situations when the beneficiary implementing an expenditure breaches regulations which are later, e.g. at the time of auditing, generally not regarded as illegal behaviour.

In this meaning, it is necessary to distinguish between the general principle of punishment and rules based on the principle of sound financial management and the recovery of unduly granted funds. This will be discussed below.
As the author of this contribution lives in the Czech Republic, where he deals with the auditing of EU funds, the legal environment of this Member State will be further discussed.

\section{Legal basis}

The rules of individual European funds and other subsidies or grants provided to the Member States differ in certain aspects. One of the reasons is that the financial allocation is administered and managed by various Directorates General (DG) of the European Commission. Further insights will be analysed in the framework of the European structural and investment funds (later referred to as "ESIF"), which consists of the European Regional Development Fund, the European Social Fund, the Cohesion Fund, the European Maritime and Fisheries Fund and the European Agricultural Fund for Rural Development.

Funds provided within these financial mechanisms fall under the principle of shared management of the European Commission and the Member States. The shared management is based on the Article 317 of The Treaty on the Functioning of the European Union (hereinafter "TFEU"), which functions as the basis for laying down the financial regulation [Regulation (EU, EURATOM) No. 966/2012], and which further defines the rules of the aforementioned Art. 317 and lays down the control and audit obligations of the Member States in the implementation of the budget and the resulting responsibilities. 
The basic legal framework for the financial management of the European structural and investment funds is given by the so-called Regulation on common provision [Regulation (EU) No. 1303/2013].

At the national level, the system of control is currently governed by the Act no. 320/2001 coll., on financial control in public administration (hereinafter "ZFK"). The system of financial control provided by control authorities according to Art. 7 to $11 \mathrm{ZFK}$ includes the financial control of facts that are relevant to the management of public funds, especially in public spending including the public financial support of those controlled or audited (hereinafter "auditee") at the time prior to their granting, during their use and after their use (primary system), and an audit provided according to the rules of the European Union. Audits performed by the audit authority (AA) are conducted in accordance with Art. 13a ZFK and Art. 127 para 1 of the Regulation on common provisions (secondary system).

\section{Status of Audit}

At the national level, the ESIF funds are reallocated from individual operational programmes (e.g. Operational Programme Transport or Operational Programme Environment) formed on the basis of the so-called Partnership Agreement between the European Commission and the Member State (the Czech Republic). The control of individual operational programs is delivered by managing authorities or intermediate bodies that have the status of fund providers. Managing authorities are responsible for setting up an adequate management and control system as well as for implementing financial controls (management verifications).

Financial control, not only of ESIF, is set on a two-level system of projects verification. First is performed by providers, followed by an additional verification performed by a different functionally independent body on a selected sample of operations ${ }^{1}$.

\footnotetext{
1 'Operation' according to Art. 2 para 9 of the Regulation on common provisions means a project, contract, action or group of projects selected by the managing authorities of the programmes concerned, or under their responsibility, that contributes to the objectives of a priority or priorities; in the context of financial instruments, an operation is constituted by the financial contributions from a programme to financial instruments and the subsequent financial support provided by those financial instruments.
}

The primary control system of the operational programmes is carried out by the managing authority of the operational programme or by the Certifying Authority (which manages the financial flows between the Member State and the European Commission), while the secondary system is ensured by an independent central Audit Authority within the Ministry of Finance of the Czech Republic.

According to the legal provisions, the managing authority is responsible for managing and implementing the operational program in accordance with the principles of sound financial management and ensures that operations are selected for funding in accordance with the criteria applicable to the operational programme and that they comply with applicable EU and national rules for the whole period of their implementation.

Within the primary control system, the managing authority is obliged to perform verification of operations / projects related to administrative, financial, technical and potentially physical aspects of operations. The primary control system shall ideally ensure that co-financed products and services are delivered and that the expenditure declared by the beneficiaries for operations has actually been incurred and complies with the EU and national rules.

The secondary control system (audit) should primarily evaluate the effectiveness of the primary control system and propose corrective measures (e.g. improving the managing and control system or financial corrections) in the case of failure.

The prerequisite for the smooth drawing from EU funds is therefore an appropriate set-up of the primary control system that is able to identify errors at an early stage of the project cycle. One limit is the fact that authorities performing the control or audit may not have the same information (certain circumstances can arise after the primary control but they will be taken into account during the audit).

The primary and secondary control are treated through inspection and surveillance issued by European authorities - corresponding Directorates General of the European Commission and the European Court of Auditors (ECA) including Supreme Audit Institutions (e.g. the Czech Supreme Audit Office). 


\section{New and more favourable legal provisions}

The possibility or suitability of taking account of new and more favourable legal provisions comes into question when the recipient breaches regulations related to public procurement at the time of tendering a public procurement. A change of rules can take place before an audit is performed on the operation.

The financial control deals with the question of the eligibility of costs. The result of the financial control is the audit protocol or audit report which is, by the character a bearer of information, not a declaration of rights and responsibilities. The audit report does not state an administrative offense, nor does it place a sentence or penalty in the case of the breach of rules related to tendering public procurements. It simply states the amount of eligible and ineligible expenditures.

The main point is that the costs related to a public procurement tendered against the law cannot be considered eligible, in the full amount or in the amount that corresponds to the seriousness of the breach, from the perspective of an audit. Any ineligible costs should be set aside from the assessment of whether the contracting authority committed an administrative offense or not whether it is possible to apply the Art. 40 paragraph 6 of the (Czech) Charter of Fundamental Rights and Freedoms which lays down that imposed penalty shall not be heavier than that which was applicable at the time the criminal offence was committed. If, subsequent to the commission of a criminal offence, the law provides for a lighter penalty, that penalty shall be applicable.

An ineligible expenditure presents an irregularity in the meaning of Art. 2 paragraph 36 of the Regulation on common provisions. In the case of non-compliance with public procurement rules a financial correction shall be based on the Commission Decision C(2013) 9527. The purpose of financial corrections is under recital $6 \mathrm{EC}$ Decision C(2013) 95272 "to restore a situation where all of the expenditure declared for financing by the Union is legal and regular, in line with the applicable national and Union rules."

The seriousness of the irregularity is laid down in the Commission Decision C(2013) 9527 as follows: "The seriousness of an irregularity related to non-compliance with

\footnotetext{
Commission Decision of 19.12.2013 on the setting out and approval of the guidelines for determining financial corrections to be made by the Commission to expenditure financed by the Union under shared management, for non-compliance with the rules on public procurement.
}

the rules on public procurement and the related financial impact to the Union budget is assessed taking into account the following factors: level of competition, transparency and equal treatment. When the non-compliance at stake has a deterrent effect to potential tenderers or when the non-compliance leads to the award of a contract to a tender other than the one that should have been awarded, this is a strong indicator that the irregularity is serious." The audit therefore examines whether the breach of public procurement rules had an impact on competition and if so, to what extent. Precisely from this it can be deduced that audits should aim to assess the compliance of relevant legal rules at that time.

The above-mentioned decision of the European Commission is not directly binding for the Member States, but to the Commission. It lays down guidelines for services of the European Commission on how they shall assess the breach of public procurement rules and what level of expenditures shall be classified as ineligible. Member States (MA and AA) should respect these guidelines in case of findings as a minimum, because when Commission asses such a finding and the financial correction is not set according to the guidelines, it can refer to a system irregularity (in the meaning of the whole Member State).

In the Czech Republic, irregularities are levied from the recipients as payment (levy) for the breach of budgetary discipline which is a process governed by tax laws. The tax administrator is bound by the principles of legality, material truth and the free evaluation of evidence among others and will apply a different approach to the principles of proportionality in determining the amount of ineligible costs / expenditure than the Commission, MA or AA. Irrespective of the success in this proceeding, the European Commission enforces the irregularities from the Member State.

\section{A practical example}

Generally, in the case of detection of a breach of a legal provision audit authority considers the breach of the provision in a way taking into account the time when the legal provisions were in force when the project was implemented and the irregularity occurred. In this context findings and the corresponding financial corrections are based on those rules and provisions in effect at the time when it happened even though there might be actually new legal provisions which are more favourable to the beneficiaries. New and more favourable legal provisions are therefore 
not taken into account retrospectively in order to grant lower financial corrections for these cases. This audit practice is based on consultations which took place in the past between auditors of the Czech audit authority and DG for Regional and Urban Policy.

However, the recent approach of the auditors of the European Court of Auditors is to take into account the later changed legal provisions which are more favourable than the legal provisions in effect at the time of the project implementation (when irregularity occurred) ${ }^{3}$.

It is obvious that in this matter a detailed opinion to cover all possible cases cannot be given and at the same time I am aware that it is always necessary to consider all aspects of a particular situation on a "case by case" basis. In particular, it is necessary to examine the reasons for which the past and newly changed legislation was adopted.

For the purpose of further analysis it is to demonstrate the above stated issue on the example of the public procurement rules.

Considering the transposition of the new EU public procurement directive 2014/24/EU into the Czech legislation Act No. 134/2016, which should have been transposed by 18 April 2016 but was effectively transposed only as of 1 October 2016, the issue of more favourable legal provisions will be certainly raised by the beneficiaries for cases of irregularities which occurred between 18 April 2016 and 1 October 2016 and also before the original planned date of the transposition of 18 April 2016.

One of the most common cases of the issue mentioned above will be the case of additional works. The previous EU public procurement directive and its Czech transposition set out relatively rigid rules for the use of negotiated procedure without publication including cases for awarding additional works. The new EU public procurement directive and its Czech transposition (EU Art. 222.4 / CZ Art. 72.2) allow to change a public contract without initiating a new award procedure, if the value of the additional works is less than $10 \%$ of the initial public contract for services or supplies, and $15 \%$ of the initial public contract for works.

In this context the Czech contracting authorities, which awarded a contract for example in December 2014, in July 2015 or in May 2016, and for which audit of the AA would found an illegal use of the negotiated procedure for awarding additional works but in the amount not exceeding

\footnotetext{
3 ECA audit in the context of PF 7194 DAS 2015 considered its finding as "other compliance issue" instead of "quantified error":
}

the limit of $10 \%$ for services/supplies and $15 \%$ for works, might argue that there should be no financial correction as the later Czech legislation on public procurement Act No. 134/2016 (valid as of 1 October 2016) legally allows to award the additional works not exceeding $10 / 15 \%$ of the initial value of the contract.

Moreover, the EU public procurement directive 2014/24/EU which specified the above stated legal provisions was at the time of the audited projects already adopted or even as of 18 April 2016 should have been effectively transposed into the Czech national legislation.

$E U$ legislation (directives) and related decision-making practice of the Commission and of the European Court of Justice ensure competitive environment among suppliers in the area of public procurement. This legislation at some point (current period) "found" that an amendment to a contract, which does not alter the subject matter of the contract and its value is not exceeding the limit of $10 \%$ for services/supplies and 15\% for works, is not a substantial modification of the public procurement contract and it can be awarded without a competition among bidders (while fulfilling also other conditions). Therefore, the current legislation in force is based on the assumption that such a modification does not distort competition.

The annex to the Commission Decision C(2013)9527 from 19 December 2013 in Article 1.3 (first paragraph) states that the percentages reflect the gravity of the irregularities and the principle of proportionality and that they apply in cases where it is not possible to quantify the financial impact for the procurement contract at stake, so in other words, the primary goal is to quantify the financial impact. The new current EU legislation related to the public procurement is based on the assumption that a certain amount of additional works awarded to the original contractor without a competition does not distort competition. Then it is possible to assume that such an award of a contract (even in the past period when the award was not in line with the legislation in force) should not have any financial implications.

When reviewing the possibilities of considering more favourable legislation and thus stating a formal breach without financial impact, we can formulate arguments in favour of taking this kind of procedure into account as well as arguments against this approach. You will find a few of them listed below.

Arguments for DISREGARDING new and more favourable provisions: 
The contracting authority intentionally (or out of negligence) breaches national legislation applicable to the area of public procurement and affected competition between potential bidders which could have resulted in a more favourable price (higher quality of delivery in terms of performance/ price) of the public procurement.

Arguments for CONSIDERING new and more favourable provisions:

EU legislation (directives/ guidelines) and the subsequent decision-making practice of the Commission and judicial institutions of the EU on the area of public procurement provide competition and a competitive environment among bidders. This legislation at some point (current period) "found" that an amendment to a contract, which does not alter the subject matter of the contract and its value does not exceed the limit of $10 \%$ for services/supplies and 15\% for works, is not a substantial modification of the public procurement contract and it can be awarded without a competition among bidders (while fulfilling also other conditions). Therefore, the current legislation in force is based on the assumption that such a modification does not distort competition.

\section{Conclusion}

From the context, it is possible to state that from the audit perspective, it is not entirely appropriate to determine financial corrections in situations when the law was breached at the time but the legislator removed such obligation from legal provisions.

This approach in Czech could be used by the audit for projects in which public contracts were launched between 26 February 2014 (the date of the adoption of the Directive 2014/24/EU) and 30 September 2016 (the last date before the entry into force of the Czech Act 134/2016, transposition of the last public procurement directive). In this context, no financial corrections shall be applied. When performing audits, only an infringement of the legislation should be stated but without applying financial corrections.

It is also an issue that cannot be, in terms of the ESIF financial controls, concluded unequivocally. The reason for that are two different levels. One of them is present between the provider and the recipient of the subsidy/ grant who would probably achieve the consideration of subsequent more favourable legislation in the tax proceedings, but the Member State does not have such a clear position with regard to the rules of shared management and the rules of the Commission Decision C(2013) 9527. All in all, it seems to be needed to close such findings taking into account new provisions at least by decreasing financial correction and if sufficient completion than to formulate "only" formal breach of rules.

\section{Acknowledgment}

To conclude, let me thank all my colleagues thanks to whom I had the opportunity to compare opinions and draw my own conclusions during countless discussions last years. A big thank you goes out to my colleagues from the Czech Ministry of Finance, especially to those from the Audit Authority.

\section{Legal Acts}

Regulation (EU, EURATOM) No. 966/2012 of the European Parliament and of the Council of 25 October 2012 on the financial rules applicable to the general budget of the Union and repealing Council Regulation (EC, Euratom) No. 1605/2002.

Regulation (EU) No. 1303/2013 of the European Parliament and of the Council of 17 December 2013 laying down common provisions on the European Regional Development Fund, the European Social Fund, the Cohesion Fund, the European Agricultural Fund for Rural Development and the European Maritime and Fisheries Fund and laying down general provisions on the European Regional Development Fund, the European Social Fund, the Cohesion Fund and the European Maritime and Fisheries Fund and repealing Council Regulation (EC) No. 1083/2006.

\section{Author biography:}

Stanislav Bureš - is a graduate of the Law Faculty of Masaryk University in Brno, the Czech Republic and deals with the area of auditing funds co-financed from the EU budget in the long term. He started his career at the Audit Authority of the Czech Ministry of Finance in 2012 as a lawyer and has been a director since 2016. Stanislav Bureš specializes in the areas of financial controls, audit, public procurement and state aid. 